\title{
ASSESSMENT OF THE ELECTORAL GEOGRAPHY OF UKRAINE: CASE OF PRESIDENTIAL ELECTIONS OF 2019
}

DOI: http://dx.doi.org/10.18509/GBP.2020.63

UDC: 328.13:342.843.1(477)"2019"

\author{
Kanat Makhanov \\ Eurasian Research Institute, Kazakhstan
}

\begin{abstract}
The study attempts to explain the geographic distribution of votes on the presidential elections of 2019 in Ukraine based on economic and location data of the districts constituting the region of the country. Taking the traditional East-West electoral division of the Ukrainian regions as a baseline the, analysis shows the persistence of the regional cleavage in the distribution of votes. Based on available data, the study attempts to incorporate the idea of the economic vote to explain the variations of vote casts across the regions of Ukraine. The results of the estimates show that the size of the average wage rate in Ukrainian districts was a relevant factor explaining the voting patterns. The locational factor also proved to be a relevant variable affecting the vote casts. Being located in the westernmost parts of the country, especially in the regions of Galicia, was a significant factor explaining the vote cast differences between candidates.
\end{abstract}

Keywords: Ukraine, presidential elections, regions, vote casts, economic vote.

\section{INTRODUCTION}

Ukraine held two-round regular presidential election on 31 March of 2019. Since the candidates failed to get an overall majority in the first round of the elections (a simple majority), the incumbent president Petro Poroshenko and Volodymyr Zelensky, who got the highest number of votes in the first round of the elections, faced each other in a runoff on April 21 of 2019. According to the Central Election Commission (CEC), 2,344 international observers from 17 countries and 19 organizations officially registered to monitor the elections admitted the compliance of the elections with democratic principles and basic international standards [1]. These elections were regarded by observation missions as generally reflecting the will of the Ukrainian people [2].

As it was expected by many [3], on April 23 of 2019 the Front-runner Volodymyr Zelensky won a landslide victory gaining $73.22 \%$ of the vote and was declared PresidentElect by the CEC. The incumbent president Petro Poroshenko took $24.45 \%$ of the vote. The election campaign was carried out in a generally professional and smooth manner across the country [4], except for Separate Districts of Donetsk and Luhansk Regions, the Autonomous Republic of Crimea and the city of Sevastopol with voter turnout of $62.86 \%$ in the first and $61.37 \%$ in the second round of the election [1]. Figure 1 depicts the map of the ultimate results of the second round of the elections.

The geographic distribution of the votes of the second round of the elections were rather unusual with overwhelming absolute victory of Volodymyr Zelensky all across the country except for Lviv region (electoral districts 115-126) and some parts of Tenopil (electoral districts 163 and 165) and Ivano-Frankivsk regions (electoral district 83) [1]. 


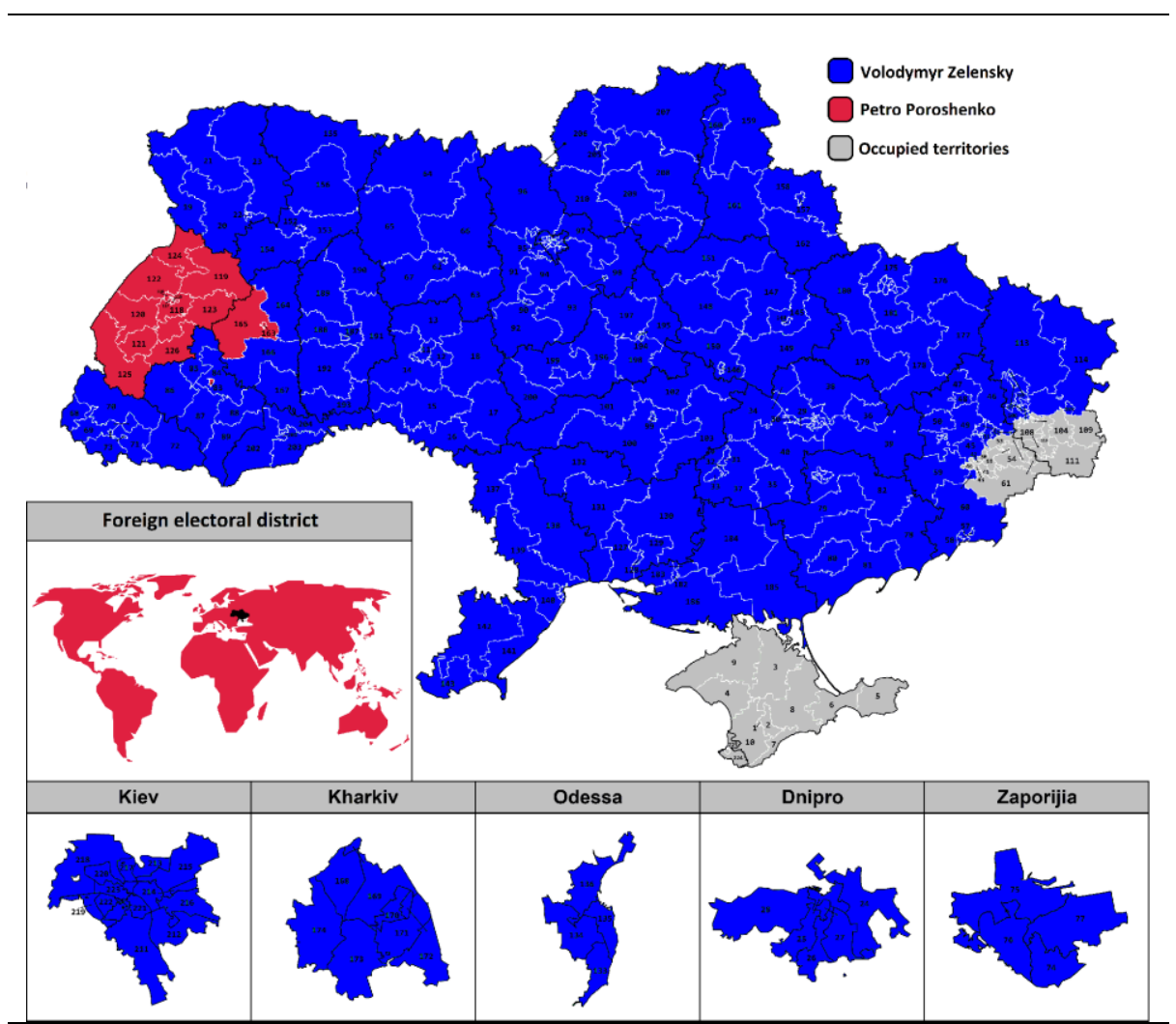

Figure 1. Results of the $2^{\text {nd }}$ round of the elections

The abovementioned electoral districts were the only ones that registered majority of the votes for Petro Poroshenko. Thus, Volodymyr Zelensky got majority of the votes in all but one of 25 regions of Ukraine where presidential elections were held. However, this kind of geographic distribution of the votes is rather similar to the previous elections held on May 25 of 2014 when Petro Poroshenko got elected with 55\% of the vote as a one round winner [5]. At that time, Petro Poroshenko won absolute majority of the votes in all across the country except for some parts of the Kharkiv region [1].

\section{LITERATURE}

Despite having democratic electoral traditions and having curious geographic electoral patterns, Ukrainian election cases receive relatively little attention from scholars in geography and most of the existing works are very recent. However, the among all studies encompassing the electoral geography of Ukraine the issue of regional polarization and East-West division is one of the most frequently discussed ones. Studies sets a comprehensive baseline in the sequence of posterior studies identifying that historical and cultural legacy of Austro-Hungarian, Polish, Romanian and Czechoslovak rule on the modern territory of Ukraine is positively related to the pro-nationalist and proindependence electoral preferences in the western parts of the country. Historical legacy and linkages of with Russian and USSR, on the other hand, is correlated with proCommunist and pro-Russian support in the eastern part of Ukraine [14].

There are studies reveals a continuous homogenization of the regions of Ukraine in terms of electoral preferences throughout 2002-2014 except for the westernmost region of Galicia and the easternmost region of Donbas during 2006-2014 [13]. [6] is one of the studies done on the electoral geography of Ukraine studying the geography of the turnout 
in Ukraine throughout 2002-2014. Discussing the decreasing gap in turnout between urban and rural areas in Ukraine [6] mentions the East-West divide of the country in most of the parliamentary elections. He assumes it to be a matter of political culture and differences in historical experiences of certain parts of the country. In another of his studies, [6] identifies Russian social networks as an important factors in propagating proRussian subscription and fomenting anti-Ukrainian sentiments in eastern regions of Ukraine [7].

[8] focuses on the East-West dichotomy in the context of Ukrainian conflict resolution attempting to map the imaginary "East-West" divide of the country outside of its borders. She argues that the East-West dichotomy in Ukraine is neither innate nor fully internalized. Her arguments suggest that the East-West polarization of the Ukraine partially derives from external factors and global trends in political affairs. There is a comprehensive work done by [16], studying the mechanism of the electoral behavior of Ukraine. Her analysis detects the relevance of ethno-cultural variables in determining the voting patterns in the regions of Ukraine. However, one of the interesting aspects of her work is that she applies the "correct voting" measure used in [17] and [18]. Her finding suggest that income level of electors are positively related with the degree of correctness of their vote casts. In general, studies covering parliamentary elections of Ukraine are more frequent than those focusing on parliamentary elections are [9], [10], [11], [12] rather than presidential elections [14], [19].

\section{EXPLAINING THE EAST-WEST ELECTORAL CLEAVAGE OF UKRAINE}

Ukrainian Presidential candidates with pro-Russian electoral agenda and advocating closer ties with the eastern neighbor have greater chances to gain much more vote cast in eastern regions than in other parts of Ukraine [12]. On the other hand, pro-European candidates with strong appeals to traditional Ukrainian culture and values usually get great majority of the votes in western regions of the country. A clear regional division of Ukraine in its electoral patterns were visible yet during the presidential elections of 1991 [19], which gives more relevance to the argument of a historical origin of the regional cleavages in Ukraine [13], [20], [21], [22]. Most often for purposes of electoral research, the regions of Ukraine are divided into East and West along the riverbed of the Dnipro River and southern regions along the coast of the Black Sea usually have the same electoral patterns as the eastern regions do [16] (Figure 3). Thus, regions like Zaporizhia, Kherson, Mykolaiv, Odessa and Crimea present electoral patterns similar to the traditional East of Ukraine. The borderline between the East and West is not fixed, however, and was shifting eastward and westward in different periods of the electoral records of the independent Ukraine. In periods of the maximum extension of the western electoral camp like in 2004 and 2010, the division between the two parts of the country looks as South-East and North-West. The maximum eastward extension of the line between East and West of the country reached as far east as the Uman-Kharkiv line [23] (Figures 5 and 6). The election of 2014 stands by as an exception because it was a snap election during a conflict with Russia (Figure 7).

When it comes to voting patterns of the East and West of Ukraine, two historical regions stand out in most of the cases. The most representative electoral behavior of the East is persistent in the region referred as Donbas, the borders of which fit into the area of the regions of Donetsk and Lugansk. The typical western electoral region of Ukraine is represented by the historical region of Galicia, the area of which almost perfectly fits into the borders of the regions of Lviv, Ivano-Frankivsk and Ternopil (Figure 2). In this regard, 
electoral preferences of some regions and territorial polarization of Ukraine often follow modern administrative borders as well as historical borders, which came into existence as mostly as a result of historical struggles between USSR, Poland in more recent historical periods and standoff clashes between Austrian and Russian empires in earlier periods [13].

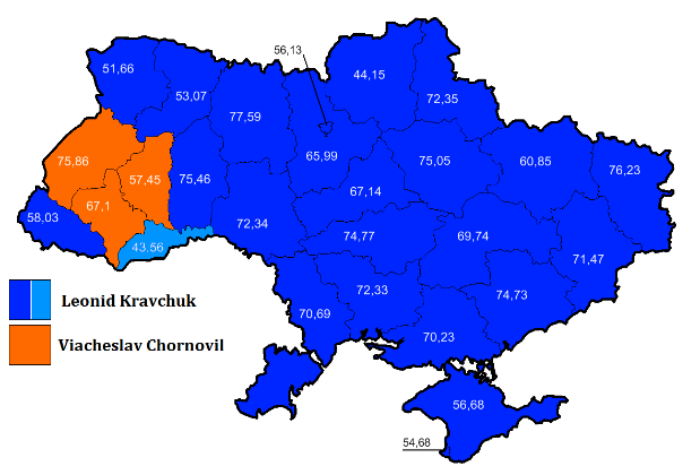

Figure 2. Results of the presidential elections of 1991.

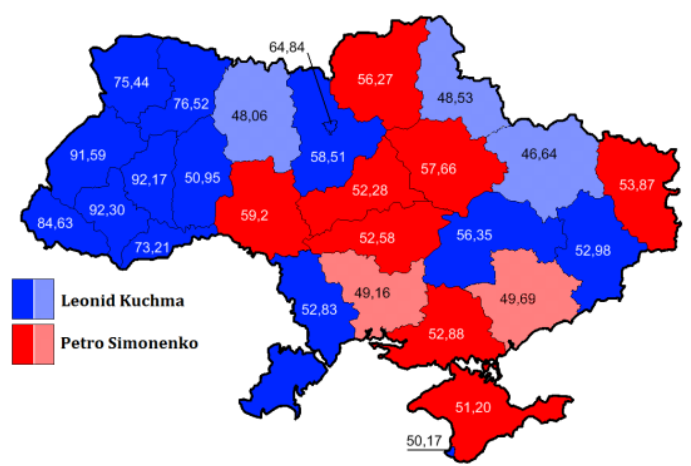

Figure 4. Results of the second round of the presidential elections of 1999.

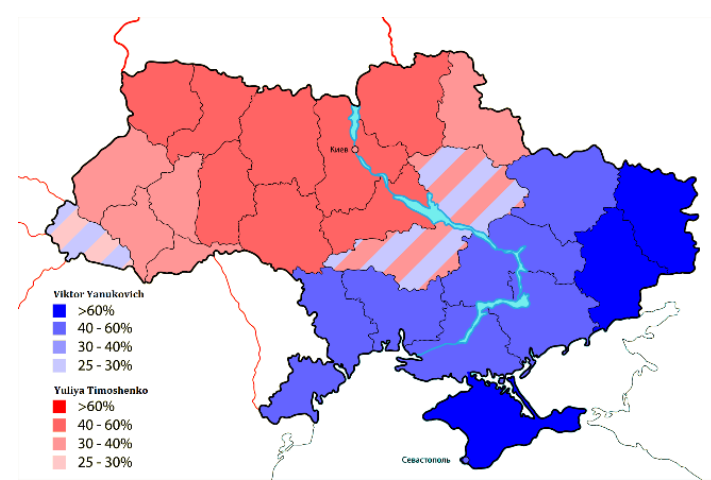

Figure 6. Results of the second round of the presidential elections of 2010.

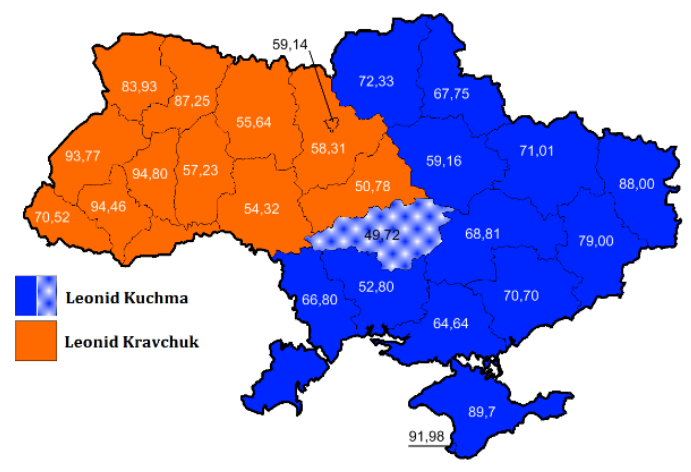

Figure 3. Results of the second round of the presidential elections of 1994.

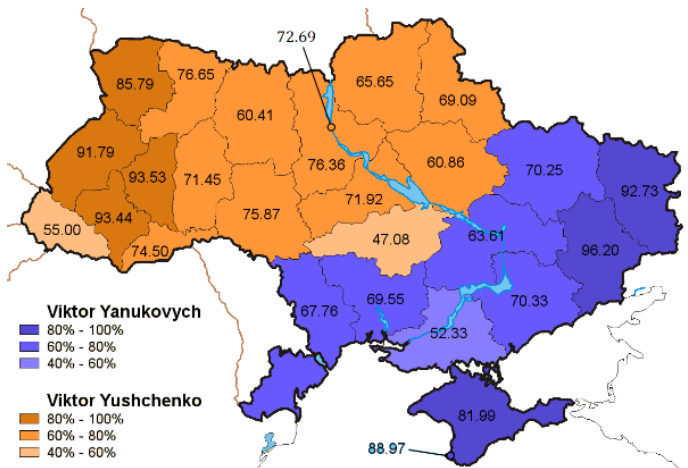

Figure 5. Results of the second round of the presidential elections of 2004.

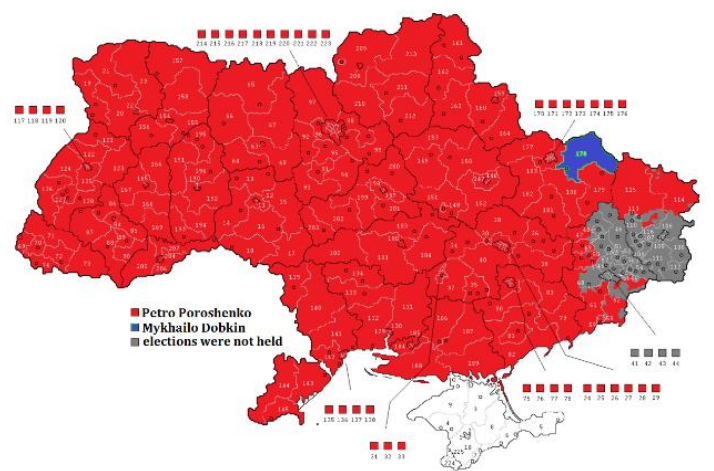

Figure 7. Results of the snap presidential elections of 2014.

One can note that higher degrees of polarization of the vote casts between East and West sharpness of separation between them contributed to more fierce confrontation of the general public opinion on the election results. The second round of the elections of 2004 is an illustrative case of clash of public opinion of the two sides when Viktor Yushchenko got more than $93 \%$ of the votes in the western regions of Galicia and won with a very high margin most parts of the western Ukraine. The opposite was true for his opponent 
Viktor Yanukovych, who received more than $90 \%$ of the votes in the easternmost region of Donbass [14]. The turmoil around the electoral results rapidly developed into the socalled "Orange Revolution". The regional context was brightly manifested during the turmoil caused by the outbreak of conflict in the eastern region of Donbas, which was manifested in not only in parliamentary [12] but also in presidential election.

The East vs West cleavage of Ukraine during electoral events can be seen in multiple dimensions and it extends beyond the electoral behavior of different parts of Ukraine. Linguistic differences between the regions are often presented as explanatory factors in shaping the cultural differences and attitudes towards politicians [24], [19], [26], [27], [25], [13] (Figure 9). Based on linguistic factor, the electorate of Ukraine can be classified as 1 - Ukrainian-speaking ethnic Ukrainians in the western regions of the country supporting pro-western and pro-European candidates; 2 - Russian-speaking ethnic Russians of east and southern regions of Ukraine, who prefer to vote for a pro-Russian candidates; and 3 - bilingual population of the center and eastern center, who often represent the swing vote [27], [30] (Figure 8).

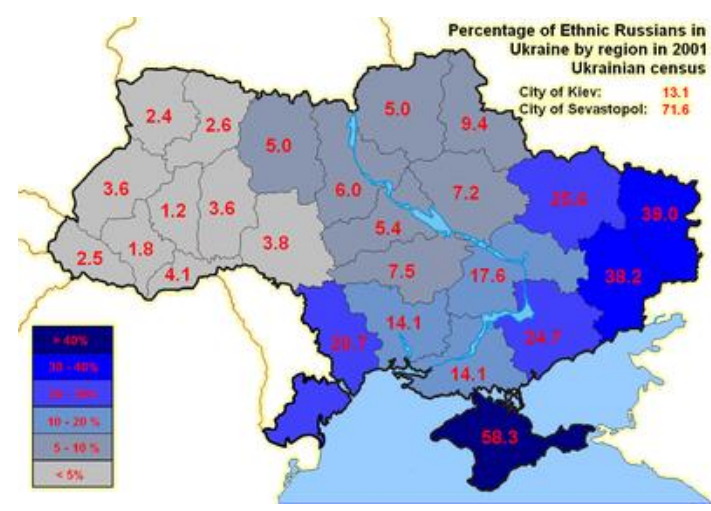

Figure 8. Ethnic map of Ukraine.

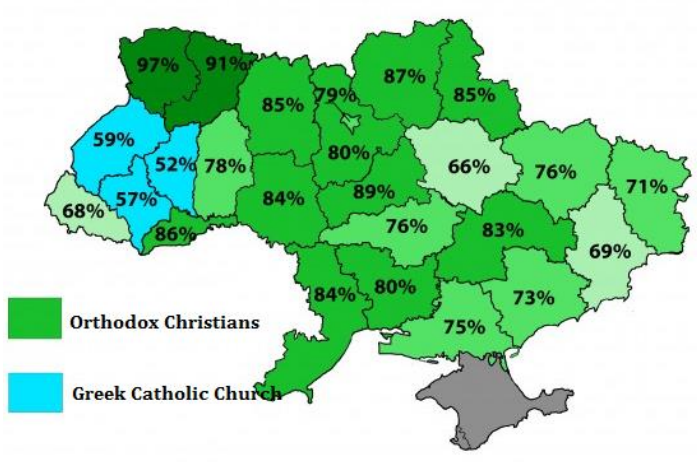

Figure 10. Religious map of Ukraine.

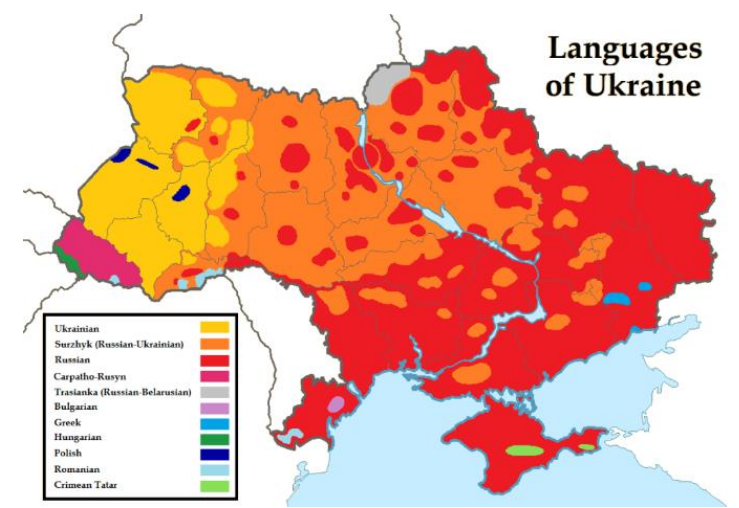

Figure 9. Linguistic map of Ukraine.

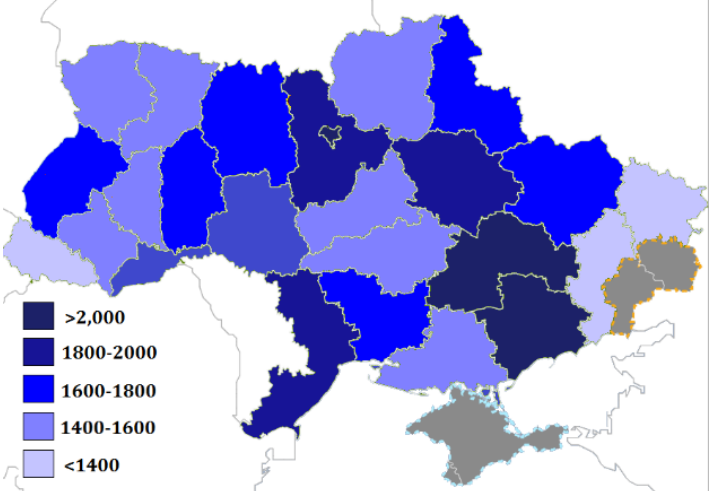

Figure 11. GDP per capita in the regions of Ukraine as of 2017.

Ethnicity of the population in the regions is also a one of the frequently mentioned and studied explanations of electoral preferences [28], [29]. Some scholar propose the relevance of historical, institutional, and cultural reasons in explaining regional differences [21], [22]. Mapping of the population based on ethic and linguistic factors backed by comprehensive data and control groups often coincide with traditional borders between of the East, South, West, and Center of the country [31], [32]. Religion has also 
been tested as a relevant predictor of vote casts and political views of the population [33], [34] (Figure 10).

Another important factor that makes the eastern regions of the country different from its western parts is the degree of urbanization of the population, which also can be understood as a predictor of political behavior of the population of Ukraine [23]. For instance, all four of the existing cities of Ukraine with population more than one million are located in eastern, southern and central parts of the country. Nine out of top ten largest cities of Ukraine are located outside of the traditional West of the country. The city of Lviv, which is considered to be the center of the historical region of Galicia, is the only city with population above 500 thousand people located in the west of the country. However, the urbanization of the population often correlates with other parameters such as industrialization, employment and income level, making it extremely difficult to identify the ultimate factor or to isolate the effect of every single predictor [14], [15] (Figure 11). There are also studies suggesting that neither of the abovementioned factors is good enough to explain the differences in electoral conduct between the East and West of Ukraine. Instead, they suppose the predicting factor to be a complex amalgam of economic and political legacies of the USSR [35], [36].

\section{DISTRICT BASED ANALYSIS}

Unlike many of the previous presidential elections in Ukraine, the elections of 2019 did not present a stark East vs West geographic division of votes. Volodymyr Zelensky's landslide victory on the elections by getting majority of the votes in 24 out of 25 regions, where the elections where held, was exalted by media as an electoral unification and the end of East vs West dichotomy [37].

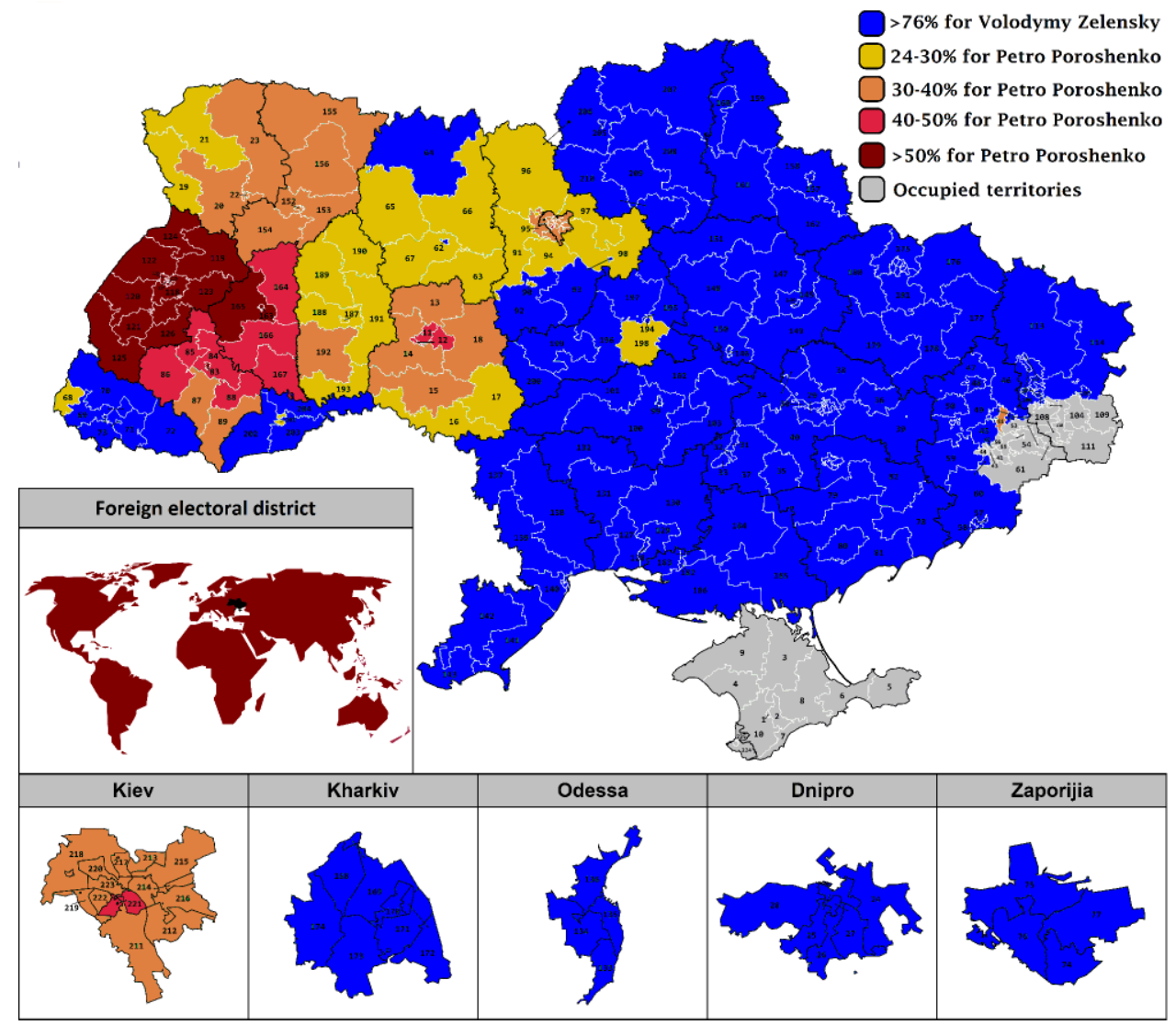

Figure 12. Percentage of distribution of votes for the incumbent candidate 
However, if we differentiate the regions by the percentage of vote casts for either of the two candidates we will see that there are substantial differences in percentages of the votes and that the border line between the East and the West is still there where it used to be during previous electoral events. The map depicted in Figure 12 shows the distribution of votes in the second round of the presidential elections of 2019 in Ukraine highlighting the electoral districts with vote casts of at least $24 \%$ for incumbent President Petro Poroshenko. $24 \%$ is the approximation for $24.45 \%$ of nationwide vote cast for Petro Poroshenko. Thus, Petro Poroshenko got more percentage of vote than on average in ten out of 25 regions that held the elections and of them correspond to traditional western electorate.

Following the idea of the competence model of retrospective voting [38] suggesting that the decision of voters are based on economic outcomes during the incumbent president's term [39] we apply it to the regional distribution of votes between the two candidates on the election of 2019. The origins of the idea can be traced back as far as to 1960 s to the theory of economic voting [42], [43], [44]. The basic premise that is followed here is that voters evaluate the performance of the incumbent head of the administration based on economic performance in their respective areas comparing their wellbeing at the moment of election to a certain reference point in the past. The concept was applied in many studies in different forms and variables for a wide range of countries [40], [41].

Following a simple logic of the economic vote theory and applying it to the regions of Ukraine we estimate the following model:

$$
V=\beta_{0}+\beta_{1} w a g e+\beta_{2} \Delta w a g e+\beta_{3} w e s t 1+\beta_{4} w e s t 2+\beta_{5} w e s t 3+\varepsilon
$$

wage - average wage in a particular district

$\Delta$ wage - percentage change of the nominal wage in a particular district west 1 - dummy $=1$ for districts inside the Galicia region and dummy $=0$ otherwise west $2-$ dummy $=1$ for districts inside the average West and dummy $=0$ otherwise west 3 - dummy $=1$ for districts inside the bigger West and dummy $=0$ otherwise

In order to estimate the model we refer to data on vote casts by each of the 199 electoral districts inside of the country that were involved in the electoral process. The data is taken from the CEC [1]. We also use data on average wage in each of the 623 districts that were under control of the Ukrainian government on the moment of elections. However, due to incompleteness of all necessary data on all variables we are interested in, the number of districts was reduced to 555 .

Table 1. Estimation results

\begin{tabular}{llllll}
\hline & Coefficient & Standard deviation & t-statistics & $\mathrm{p}$-value \\
\hline Const. & 7.44710 & 1.30748 & 5.696 & $2.00 \mathrm{e}-08^{* * *}$ \\
$\beta_{1}$ & 0.000639709 & 0.000159094 & 4.021 & $6.61 \mathrm{e}-05^{* * *}$ \\
$\beta_{2}$ & -0.0525071 & 0.0331761 & -1.583 & 0.1141 \\
$\beta_{3}$ & 23.9907 & 0.837539 & 28.64 & $4.67 \mathrm{e}-111^{* * *}$ \\
$\beta_{4}$ & 11.5938 & 0.917114 & 12.64 & $2.48 \mathrm{e}-032^{* * *}$ \\
$\beta_{5}$ & 4.00894 & 0.952446 & 4.209 & $3.00 \mathrm{e}-05^{* * *}$ \\
\hline & & $R^{2}$ & 0.802501 \\
\cline { 3 - 4 } & & & Adjusted $R^{2}$ & 0.800702 \\
\hline
\end{tabular}


The estimation results shown in Table 1 indicate the relevance of four out of five variables introduced in explaining the percentage of vote casts for the incumbent candidate on the second round of the presidential elections of 2019 in Ukraine. In particular, the average wage rates, and locations of districts inside all three types of the electorally shaped West of Ukraine are statistically significant in explaining the vote casts for pro-western incumbent candidate. Thus, higher wage rates in districts of Ukraine during the period of elections contribute to higher votes casts for the incumbent candidate. The sensitiveness it of votes to average wage rate is very low though. According to the model, the average wage in districts of Ukraine should be increased to 1563 local currency units (nearly $\$ 58.2$ ) to get one additional percent of vote cast. Surprisingly, the change of the average wage rate during 2017-2018 was not found to be a relevant predictor of votes the incumbent candidate.

The coefficients obtained for dummy variables of location go in line with the idea that western location of districts is strong factor that affects the percentage of votes for prowestern candidate. Location of a district within the border of the historical region of Galicia gave almost additional percentages of vote casts for a candidate that is perceived as a pro-western. As it was expected, this coefficient is smaller for wider understanding of the Ukrainian West. Location of a particular district just west of the Dnipro River ensured $11.59 \%$ additional votes for the pro-western candidate. The fact of being located in a wider understanding of the electoral West of Ukraine, which cover geographical West, Center and North of Ukraine, gave additional $4 \%$ of votes for the incumbent candidate.

\section{CONCLUSION}

A simple analysis and mapping of the results of the second round of the presidential elections of 2019 in Ukraine show that the traditional East-West electoral cleavage of Ukraine persists. The districts of Ukraine located west of the Dnipro River provided significantly more votes for President Poroshenko, who was perceived as pro-western candidate. Although it did not affect the ultimate outcomes of the election, it did change the distribution of votes across the regions of Ukraine. By incorporating the idea of the economic voting [42], [43], [44] along with the regional components to an OLS model we found statistically significant estimators for some of the variables. In particular, the model suggests that districts with higher wage rate relative to the rest of the country provided higher vote casts for the incumbent candidate. On the other hand, the change of the average wage rate was not significant enough to explain the variations of vote casts across the districts of Ukraine. This fact questions the validity of the relevance of the general idea of the economic vote. However, the major problem with testing the economic vote is the availability of relevant data and the limitedness of this analysis does not allow neither to confirm nor to reject it.

The model also showed that location of the districts did play a significant role in the distribution of votes. The fact of being located in the regions of Galicia meant nearly $24 \%$ more of vote cast for the perceived pro-western candidate. The tendency to vote for the incumbent pro-western candidate were reduced as for districts located east of the core West of Ukraine. Hence, geographic location of the Ukrainian districts was a relevant predictor of vote casts. 


\section{REFERENCES}

[1] Central Election Commission of Ukraine, Results of voting in Ukraine ( https://www.cvk.gov.ua/pls/vp2019/wp300pt001f01=720.html).

[2] Preliminary Statement of the IRI International Observation Mission to Ukraine July (https://www.iri.org/sites/default/files/2019.7.22_preliminary_statement_of_the_iri_internationa 1_observation_mission_to_ukraine.pdf).

[3] Grajewski, M. Presidential elections in Ukraine. EPRS | European Parliamentary Research Service, Ukraine, p 1, 2019.

[4] International Foundation for Electoral Systems. Presidential Election in Ukraine: PostElection Report

(https://www.ifes.org/sites/default/files/ifes_2019_presidential_election_in_ukraine_postelection_report_may_2019.pdf).

[5] Yakymenko, Y. Ukraine's Party System Evolution: 1990-2017, The publication is supported by the Ukrainian Office of Konrad Adenauer Foundation, 2017.

[6] Dobysh, M.P. Territorial Patterns of Turnout and Representation in Parliamentary Elections 2002-2014 in Ukraine, Vestnik: Geographic and Geological Sciences, Ukraine, vol. 23, pp 69$81,2018$.

[7] Dobysh, M.P. Euromaidan and conflict in Eastern Ukraine in social networking sites: Territorial differences of pro-Russian subscriptions in Ukraine, Hungarian Geographic Bulletin, Ukraine, vol. 68, pp 51-64, 2019.

[8] Hobova, Y. East-West dichotomy in the context of Ukrainian conflict resolution, Cognition, Communication, Discourse, vol. 17, pp 92-102, 2018.

[9] Clem, R. S. \& Craumer, P. R. Orange, Blue and White, and Blonde: The Electoral Geography of Ukraine's 2006 and 2007 Rada Elections, Eurasian Geography and Economics, vol. 49, pp 127-151, 2008.

[10] Craumer, P. R., \& Clem, J. I. Ukraine's Emerging Electoral Geography: A Regional Analysis of the 1998 Parliamentary Elections, Post-Soviet Geography and Economics, vol. 40, pp 1-26, 1999.

[11] Shevel, O. The parliamentary elections in Ukraine, October 2014. Electoral Studies, 39 (October 2014), pp 159-163, 2015.

[12] Shevel, O. (2015), The parliamentary elections in Ukraine, October 2014, Electoral Studies, vol. 39, pp 159-163, 2014.

[13] Dobysh, M. Territory, Place, Scale, and Polarization of Electoral Preferences in Ukraine, 2002-2014, Vestnik: Geographic and Geological Sciences, Ukraine, vol. 73, pp 63-68, 2018.

[14] Katchanovski, I. Regional Political Cleavages and Electoral Behavior in Ukraine in 19912004, Conference: Annual Meeting of the American Political Science Association, Washington, DC, 2005.

[15] Craumer, P. R., \& J. I. Clem, Ukraine's Emerging Electoral Geography: A Regional Analysis of the 1998 Parliamentary Elections, Post-Soviet Geography and Economics, vol. 40, pp 1-26, 1999.

[16] Surzhko-Harned L.M. The Ukrainian Voter: Electoral Behavior in a New Democracy, PhD. Dissertation, University of Pittsburgh.

[17] Zhukov, Y. M., \& Talibova, R. Stalin's terror and the long-term political effects of mass repression. Journal of Peace Research, vol. 55, pp 267-283, 2018.

[18] Lau, R.R., David P. Redlawsk, and David J. Andersen. An Exploration of Correct Voting in Resent US Presidential Elections, American Journal of Political Science, vol. 52, pp 395-411, 2008.

[19] Clem, R.S. P.R. Craumer, Shades of Orange: The Electoral Geography of Ukraine's 2004 Presidential Elections Eurasian Geography and Economics, vol. 46, pp 364-385, 2005.

[20] Zhukov, Y. M., \& R. Talibova. Stalin's terror and the long-term political effects of mass repression. Journal of Peace Research, vol. 55, pp 267-283, 2018. 
[21] Abdelal, R. Memories of Nations and States: Institutional History and National Identity in Post-Soviet Eurasia, Nationalities Papers, vol. 30, pp 459-484, 2002.

[22] Roper, S. \& Flesnic F. Historical Legacies and Their Impact on Post-Communist Voting Behaviour, Europe-Asia Studies, vol. 55, pp 119-131, 2003.

[23] Karácsonyi D., K. Kocsis, K. Kovály, J. Molnár \& L. Póti. East-West Dichotomy and Political Conflicting Ukraine - Was Huntington Right?, Hungarian Geographical Bulletin, vol. 63, pp 99-134, 2014.

[24] Barrington, L.W \& Herron E.S. One Ukraine or Many? Regionalism in Ukraine and Its Political Consequences, Nationalities Papers, vol. 32, 2004.

[25] Pirie, P. National Identity and Politics in Southern and Eastern Ukraine, Europe-Asia Studies, vol. 48, pp 1079-1104, 1996.

[26] Ryabchuk, M.A, Future Ukraine: One Nation, Two Languages, Three Cultures?, Ukrainian Weekly, vol. 23, 1999.

[27] Shevel, O. Nationality in Ukraine: Some Rules of Engagement, East European Politics and Societies, vol. 16, pp 386-413, 2002.

[28] Bremmer, I. The Politics of Ethnicity: Russians in the New Ukraine, Europe-Asia Studies, vol. 46, pp 261-283, 1994.

[29] Gee, G.K., Geography, Nationality, and Religion in Ukraine: A Research Note, Journal of Scientific Study of Religion, vol. 34, pp 383-390, 1995.

[30] Barrington, L.W. \& Herron E.S. One Ukraine or Many? Regionalism in Ukraine and Its Political Consequences, Nationalities Papers, vol. 32, 2004.

[31] Inglehart, R. \& Norris P. The Developmental Theory of the Gender Gap: Womens' and Men's voting Behavior in Global Perspective, International Political Science Review, vol. 21, pp 441463, 2000.

[32] Inglehart, R. \& P. Norris. Rising tide: Gender Equality and Cultural Change Around the World, Cambridge, UK; New York: Cambridge University Press. pp 84-87, 2003.

[33] Layman, G. Religion and Political Behavior in the United States: The Impact of Beliefs, Affiliations, and Commitment from 1980 to 1994, Public Opinion Quarterly, vol. 61, pp 288-316. 1997

[34] Lijphart, A. Religious vs. Linguistic vs. Class Voting : The "Crucial Experiment" of Comparing Belgium, Canada, South Africa, and Switzerland, The American Political Science Review, vol. 73, pp 442-458, 1979.

[35] Kubicek, P. Regional Polarization in Ukraine: Public Opinion, Voting and Legislative Behavior, Europe-Asia Studies, vol. 52, pp 273-294, 2000.

[36] O'Loughlin, J.O. Political Geography of Civic Engagement in Ukraine, 1994-1998. PostSoviet Geography and Economics, vol. 39, pp 233-266, 1999.

[37] How Ukraine's new president broke down a historic divide, washingtonpost.com, (https://www.washingtonpost.com/politics/2019/05/01/is-this-new-era-ukrainian-politics/).

[38] Persson, T. \& G. Tabellini. Macroeconomic Policy, Credibility and Politics, New York: Harwood Academic, 1990.

[39] Alesina, A. \& H. Rosenthal. Partisan Politics, Divided Government and the Economy, New York: Cambridge University Press, 1995.

[40] Campello, D. \& C. Zucco. Presidential Success and the World Economy, Journal of Politics, vol. 78, pp 589-602, 2016.

[41] Virmani, A. Economic Growth, Governance and Voting Behavior: an Application to Indian Elections, Indian Council for Research on International Economic Relations Working Paper No. 138, 2004.

[42] Downs, A. An Economic Theory of Democracy, $1^{\text {st }}$ edition, New York, NY: Harper, 1957.

[43] Tufte, E. R. Political Control of the Economy, Princeton, NJ: Princeton University Press, 1978.

[44] Kramer, G.H. Short-Term Fluctuations in U.S. Voting Behavior, 1896-1964, American Political Science Review, vol. 65(1), pp 131-143, 1971. 